\title{
Keefektifan Model Pembelajaran Cooperative Script Terhadap Hasil Belajar Mata Pelajaran Bahasa Inggris
}

\author{
Alamsah Ade Pradana ${ }^{1 *}$, Supandi², Iin Purnamasari ${ }^{3}$ \\ 1,2,3 PGSD Universitas PGRI Semarang
}

A R T I C L E I N F O

Article history:

Received 20 August 2018

Received in revised form

9 September 2018

Accepted 15 October 2018

Available online 25

November 2018

\section{Kata Kunci:}

Model Script, Hasil Belajar,

Bahasa Inggris.

Keywords:

Script Model, Learning

Outcomes, English.

\begin{abstract}
A B S T R A K
Tujuan yang akan dicapai dalam penelitian ini adalah untuk mengetahui keefektifan model pembelajaran Cooperative Script efektif terhadap hasil belajar bahasa inggris kelas III di SD Negeri 03 Kalitorong Kabupaten Pemalang, dilihat pada ketuntasan dan hasil belajar. Jenis penelitian ini adalah penelitian kuantitatif dengan metode eksperimen berbasis proyek dalam bentuk rancangan penelitian pre eksperimental dengan jenis one-group pretest-posttest design. Jumlah sampel penelitian terdiri dari 20 siswa kelas III Sekolah Dasar Negeri 03 Kalitorong Kabupaten Pemalang. Instrumen yang digunakan berupa tes dan dokumentasi. Hasil penelitian menunjukkan bahwa model pembelajaran Cooperative Script memberikan perbedaan signifikan terhadap hasil belajar siswa yang dibuktikan dengan perolehan thitung sebesar 9,542 sehingga thitung lebih besar dari pada ttabel $(9,542>$ 1,729 ). Hasil belajar siswa dapat dilihat dari perolehan posttest yang lebih tinggi dari pada nilai pretest. Rata-rata nilai pretest diperoleh 54,8 sedangkan posttest diperoleh rata-rata 77,45 . Berdasarkan hasil penelitian ini saran yang dapat disampaikan adalah supaya model pembelajaran Cooperative Script dapat digunakan sebagai salah satu alternatif guru dalam mengajar.
\end{abstract}

\section{A B S T R A C T}

The objective of the study is to find out the effectiveness of Cooperative Script model to the learning outcomes of English subject in III grade of SD Negeri 03 Kalitorong from the minimum score they get. This research belongs to quantitative experimental research using pre experimental design (one-group pretest-posttest design). Samples of the research are 20 students from III grade of SD Negeri 03 Kalitorong. Instrument of the research are test and documentation. Result of the research show that learning model of cooperative script gave the significant result to the learning outcomes which proved by the number of thitung sebesar 9,542 so thitung is higher than ttabel $(9,542>1,729)$. Students learning outcomes can be seen from the number of posttest which is higher than pretest The average of pretest is 54,8 and posttest is 77,45 . Based on the result, the researcher give a suggestion that cooperative script can be used as an alternative in English learning. 


\section{Pendahuluan}

Pendidikan adalah usaha sadar dan terencana untuk mewujudkan suasana belajar dan proses pembelajaran agar peserta didik secara aktif mengembangkan potensi dirinya untuk memiliki kekuatan spiritual, keagamaan, pengendalian diri, masyarakat, bangsa dan negara (UU RI No. 20 Tahun 2003 Tentang Sistem Pendidikan Nasional). Pendidikan formal di Indonesia terdiri dari beberapa jenjang pendidikan. Sekolah Dasar merupakan jenjang pendidikan di dasar yang ada di Indonesia. Sekolah Dasar merupakan lembaga pendidikan formal yang di selenggarakan untuk menggali dan mengembangkan potensi peserta didik yang bertujuan untuk memberi pengetahuan dan keterampilan dasar melalui berbagai macam pelajaran.

Menurut Mirasa (dalam Susanto, 2013: 70) menyatakan bahwa pendidikan sekolah dasar memiliki tujuan mengembangkan kemampuan yang mendasar setiap siswa, dimana setiap siswa belajar secara aktif karena adanya dorongan dalam diri dan adanya suasana yang memberikan kemudahan bagi perkembangan dirinya secara optimal.

Agar terciptanya tujuan pendidikan maka diperlukan suatu pembelajaran yang baik karena pembelajaran merupakan proses interaksi guru dengan peserta didik dan sumber belajar pada suatu lingkungan belajar. Pembelajaran juga merupakan bantuan yang diberikan oleh pendidik kepada siswa agar memperoleh informasi, kemampuan, serta membentuk sikap (attitude) peserta didik yang nantinya diterapkan dalam kehidupan sehari-hari. Pembelajaran yang baik meliputi kemampuan profesional guru dalam mengajar, penggunaan model ataupun metode yang digunakan dalam pembelajaran.

Menurut Permendikbud NO 22 Tahun 2016 tentang standar proses pendidikan dasar dan menengah. "Proses pembelajaran pada satuan pendidikan diselenggarakan secara interaktif, inspiratif, menyenangkan, menantang, memotivasi, pesertadidik untuk berpartisipasi aktif, serta memberikan ruang yang cukup bagi prakarsa, kreativitas dan kemandirian sesuai dengan bakat, minat, dan perkembangan fisik serta psikologis pesertadidik". Untuk itu setiap satuan pendidikan melakukan perencanaan pembelajaran, pelaksanaan proses pembelajaran serta penilaian proses pembelajaran untuk meningkatkan efisiensi dan efektivitas ketercapaian kompetensi lulusan.

Pendidikan adalah faktor utama pembangunan sumber daya manusia bagi suatu bangsa. Pendidikan yang baik dan berkualitas akan menghasilkan sumber daya yang baik dan berkualitas juga. Dalam dunia pendidikan tidak hanya memberikan pembelajaran berupa materi tetapi juga berfokus pada perkembangan psikologi anak. Sekolah Dasar merupakan jenjang pendidikan dasar yang berperan serta dalam perkembangan psikologi anak sehingga di sekolah dasar anak didik dari nol sampai anak ke jenjang pendidikan dan pembelajaran sesuai dengan umurnya.

Maka dari itu agar pembelajaran di sekolah sesuai dengan apa yang diharapkan maka setiap satuan pendidikan harus melakukan perencanaan pembelajaran, pelaksanaan proses pembelajaran serta penilaian proses pembelajaran untuk meningkatkan efesiensi dan efektivitas ketercapaian kompetensi lulusan serta diperlukan suatu inovasi dalam pembelajaran serta Guru dituntut untuk memiliki kemampuan yang baik dalam menyampaikan materi pembelajaran kepada siswa. Kemampuan guru ini dapat dilihat pada kemampuannya mengajar dalam proses belajar mengajar yang aktif dan kreatif sehingga siswa dapat mencapai tujuan pembelajaran yang diharapkan serta siswa dapat memahami arti dari pelajaran yang dipelajari.

Berdasarkan Observasi dan studi pendahuluan di SD Negeri 03 Kalitorong Kabupaten Pemalang dengan Guru kelas III (tiga) Mata Pelajaran Bahasa Inggris hasil belajar peserta didiknya rendah. Hal ini terbukti terdapat hasil pembelajaran yang rendah pada pelaksanaan ulangan harian. Kriteria Kelulusan Minimal (KKM) mata pelajaran Bahasa Inggris pada SD tersebut yaitu 65. Dari jumlah 20 siswa yang ada. Presentase ketuntasan ulangan harian di SD Negeri 03 Kalitorong Kabupaten Pemalang mencapai 61,53\%, sedangkan Presentase ketidaktuntasannya mencapai 38,46\%. Menurut Guru kelas III Mata Pelajaran Bahasa Inggris nilai siswa yang kurang dari KKM dalam pembelajaran Bahasa Inggris terjadi karena siswa mengalami kesulitan pemahaman dan ketidakpahaman inilah yang mempengaruhi hasil belajar siswa ketika ulangan harian.

Proses Pembelajaran yang berlangsung di Sekolah Dasar Negeri 03 Kalitorong Kabupaten Pemalang yaitu Guru melakukan kegiatan pembelajaran dengan model pembelajaran konvensional sehingga kurang menarik perhatian siswa. Proses pembelajaran yang kurang interaktif dan menarik membuat siswa bosan dan hasil pembelajaran siswa yang rendah. Rendahnya hasil belajar siswa kelas III SD Negeri 03 Kalitorong Kabupaten Pemalang dalam proses pembelajaran mendorong untuk dilakukannya penelitian. Hal ini bertujuan untuk meningkatkan hasil belajar siswa. Sesuai dengan tujuan pendidikan maka, untuk meningkatkan hasil belajar siswa kelas III pada mata pelajaran Bahasa Inggris menggunakan model pembelajaran yang menarik dan mudah dipahami oleh siswa. Dalam penelitian ini menggunakan model pembelajaran Cooperative Script. 
Peneliti menggunakan metode Cooperative Script terhadap hasil belajar siswa mata pelajaran bahasa inggris berdasarkan penelitian sebelumnya yang telah dilakukan oleh Nurul Iva Andriani. Dari hasil penelitian Nurul Iva Andriani di SMA Brawijaya Smart School Malang dengan menggunakan model cooperative script. Model Cooperative ternyata lebih baik dari pada model pembelajaran konvensional. Dapat dikatakan bahwa pembelajaran dengan menggunakan medel cooperative script efektif mengoptimalkan kemampuan berpikir kritis dan hasil belajar IPA siswa di SMA Brawijaya Smart School Malang.

Dengan adanya peningkatan kemampuan berpikir kritis dan hasil belajar siswa yang dilakukan di SMA Brawijaya Smart School Malang. Maka, peneliti juga mengharapkan penerapan model pembelajaran cooperative script di SD Negeri 03 Kalitorong Kabupaten Pemalang dapat meningkatkan hasil belajar Bahasa Inggris.

Berhasil tidaknya proses pembelajaran di sekolah di pengaruhi oleh banyak faktor. Faktor yang paling penting yaitu guru dan siswa. Guru merupakan faktor terpenting dalam lingkungan sekolah. Dalam proses kegiatan belajar mengajar guru berperan sangat penting menentukan berhasil tidaknya pembelajaran. Karena belajar itu adalah sebuah proses interaksi antara pendidik dalam hal ini (guru) dan peserta didik (siswa).

Menurut Slavin (dalam Shomin 2014:49) Cooperative Script merupakan salah satu bentuk model pembelajaran kooperatif. Hal tersebut sangat membantu dalam mengembangkan serta mengaitkan faktafakta dan konsep - konsep yang pernah didapatkan dalam pemecahan masalah.

Menurut Huda Cooperative Script adalah salah satu strategi pembelajaran dimana siswa bekerja secara berpasangan dan bergantian secara lisan dalam mengikhtisarkan bagian - bagian materi yang dipelajari. Dan dalam model cooperative script dapat kita amati proses keterampilan siswa dalam berinteraksi dan bergaya bahasa. Strategi atau model pembelajaran ini ditujukan untuk membantu siswa berpikir secara sistematis dan berkonsentrasi pada mata pelajaran. Model pembelajaran Cooperative Script dapat membantu siswa mengingat materi dengan cara mencatat ide pokok yang disampaikan siswa pembicara (Nur, 2017).

Berdasarkan latar belakang diatas maka perlu dilakukan penelitian dengan judul "Keefektifan model pembelajaran cooperative Script Terhadap Hasil Belajar Bahasa Inggris Siswa SD Negeri 03 Kalitorong Kabupaten Pemalang".

\section{Metode}

Penelitian ini dilaksanakan di SD Negeri 03 Kalitorong Kabupaten Pemalang. Penelitian ini dilaksanakan pada semester II Tahun Ajaran 2018/2019. Penelitian ini menggunkan dua variabel yaitu variabel bebas dan variabel terikat. Dalam penelitian ini yang menjadi variabel bebas adalah model pembelajaran cooperative script dan yang menjadi variabel terikat adalah hasil belajar bahasa inggris siswa kelas III SD Negeri 03 Kalitorong Kabupaten Pemalang. Metode yang digunakan dalam penelitian ini adalah metode penelitian Kuantitatif dengan desain penelitian Pre-experiment Design dengan bentuk one group pretest posttest design.

Teknik pengumpulan data yang digunakan dalam penelitian ini yaitu tes. Instrumen menggunakan tes (pretest-posttest) berupa tes pilihan ganda. Wawancara terstruktur, observasi dan dokumentasi yang dilakukan dalam kegiatan pembelajaran di kelas. Nilai pretest dan posttest dinyatakan tuntas jika memenuhi KKM. Adapun Kriteria Ketuntasan Minimal (KKM) mata pelajaran Bahasa Inggris SDN 03 Kalitorong yaitu 70. Perhitungan nilai pretest dan posttest setelah diberi perlakuan hasilnya berbeda.

\section{Hasil dan Pembahasan}

Awal dari penelitian ini adalah membuat proposal dan instrumen soal dari mata pelajaran bahasa inggris dengan dengan menggunakan soal uji coba sebanyak 30 soal pilihan ganda beserta kisi-kisi soalnya. Tiga puluh butir soal tersebut di uji cobakan pada siswa kelas III SDN 02 Kalitorong Kabupaten Pemalang yang jumlah siswanya sebanyak 20.

Dari hasil analisis instrumen soal tersebut terdapat 20 soal yang digunakan sebagai pretest dan posttest dari 30 soal yang di uji cobakan di kelas III SDN 02 Kalitorong Kabupaten Pemalang. Nilai awal yang digunakan dalam penelitian ini didapat dari nilai evaluasi awal sebelum siswa di berikan perlakuan yang selanjutnya disebut Pretest, sedangkan nilai akhir didapat dari nilai evaluasi yang dikerjakan siswa setelah menerima perlakuan yang di sebut dengan posttest pada siswa kelas kontrol maupun eksperimen.

Nilai pretest dan posttest dinyatakan tuntas jika memenuhi KKM. Adapun Kriteria Ketuntasan Minimal (KKM) mata pelajaran Bahasa Inggris SDN 03 Kalitorong yaitu 70. Perhitungan nilai pretest dan 
posttest setelah diberi perlakuan hasilnya berbeda. Berikut tabel nilai prestest dan posttest siswa kelas III SDN 03 Kalitorong Kabupaten Pemalang.

Tabel 1. Nilai pretest dan posttest

\begin{tabular}{lll}
\hline \multicolumn{1}{c}{ Kategori } & \multicolumn{1}{c}{ Pretest } & Postest \\
\hline Terendah & 24 & 47 \\
Tertinggi & 80 & 98 \\
Rata-rata & 54,8 & 77,45 \\
Siswa tuntas & $5(35 \%)$ & $15(85 \%)$ \\
\hline
\end{tabular}

Berdasarkan Tabel 4.1 nilai rata-rata pretest atau sebelum diberi perlakuan siswa SDN 03 Kalitorong dalam mata pelajaran Bahasa Inggris adalah 70,00 dengan nilai terendah 24 dan nilai tertinggi 80. Siswa yang mendapat nilai diatas Ketuntasan Kriteria Minimal (KKM) yaitu 5 siswa dan yang tidak tuntas ada 15 siswa. Setelah diberi perlakuan berupa penggunaan model pembelajaran Cooperative Script nilai rata-rata postest menjadi 77,45 dengan nilai tertinggi 98 dan nilai terendah 47 serta terdapat kenaikan jumlah siswa yang tuntas atau lebih dari Kriteria Ketuntasan Minimal (KKM) menjadi berjumlah 15 siswa dan yang tidak tuntas berjumlah 5 siswa.

Berdasarkan perbandingan analisis data pretest dan postest dapat disimpulkan bahwa perolehan data postest lebih baik dibandingkan pretest.

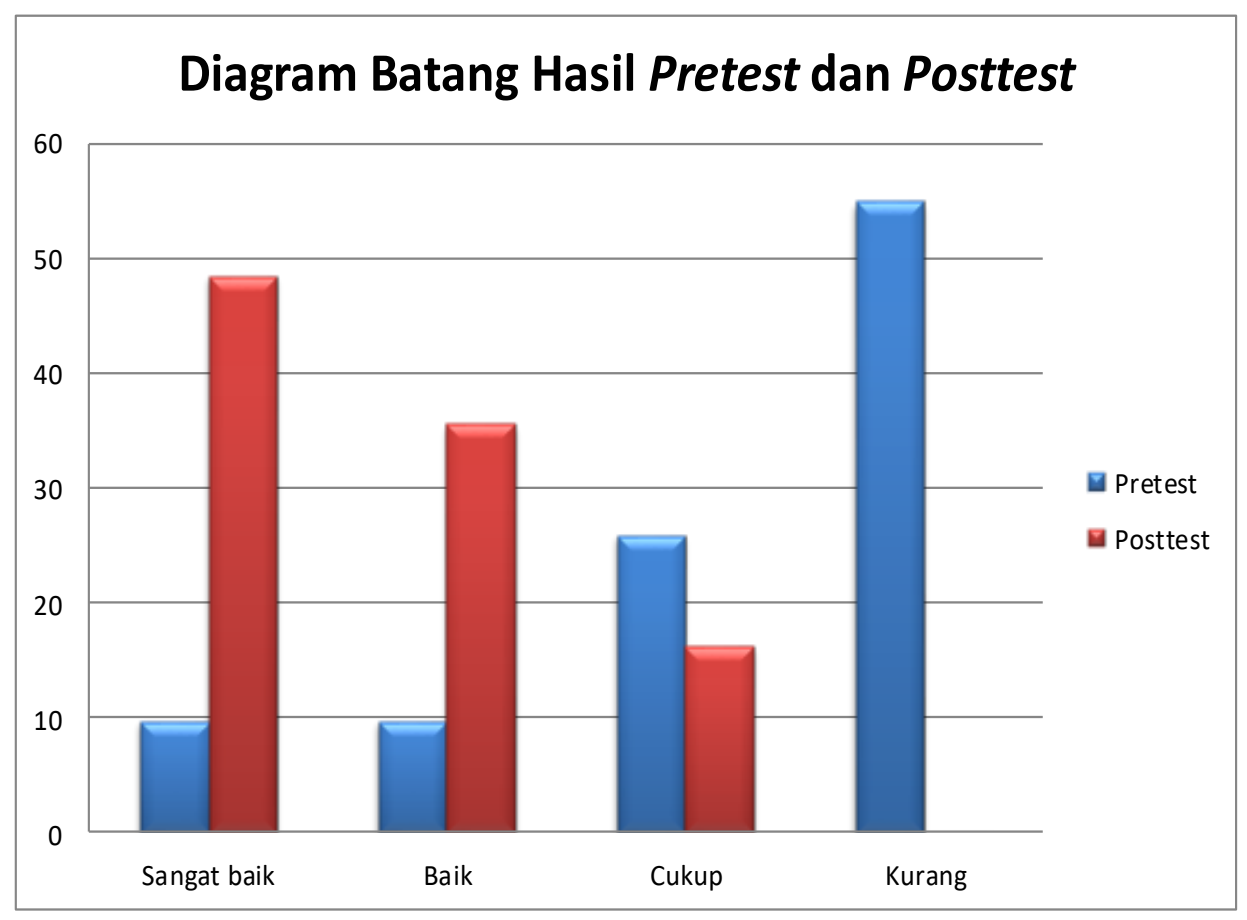

Gambar 1. Hasil Prestest dan Postest

Uji persyaratan data dilakukan setelah diberikan tes pada kedua kelompok sampel maka didapatkan data awal dan akhir yang kemudian dilakukan analisis data. Perhitungan yang digunakan untuk mengetahui normalitas data awal sampel menggunakan uji Liliefors, pada taraf signifikan 5\%.

Kriteria dalam uji normalitas ini adalah:

Lo < Ltabel, maka populasi berdistribusi normal

Lo $\geq$ Ltabel, maka populasi tidak berdistribusi normal

Tabel 2. Hasil Uji Normalitas Awal (pretest) 


\begin{tabular}{lllll}
\hline Kelompok & $\mathrm{N}$ & $\mathrm{L}_{0}$ & $L_{\text {tabel }}$ & Kesimpulan \\
\hline Kelas & 20 & 0,0761 & 0,170 & Berdistribusi Normal \\
\hline
\end{tabular}

Berdasarkan Tabel 1.2 perhitungan uji normalitas diperoleh harga mutlak selisih yang paling besar $\mathrm{L} 0=0,171$ dengan $\mathrm{n}=20$ dan taraf signifikan $=5 \%$ dari daftar nilai kritis $\mathrm{L}$ didapat Ltabel $=0,170$ karena $\mathrm{L} 0<$ Ltabel yaitu $0,0761<0,170$ maka $\mathrm{H}_{0}$ diterima sehingga populasi berdistribusi normal.

Uji hipotesis pada penelitian ini peneliti menggunakan uji-t dengan data nilai hasil belajar pretest dan posttest siswa kelas eksperimen.

Hipotesis statistik untuk keperluan $t$-test adalah sebagai berikut:

$H_{a}: t_{\text {hitung }}>t_{\text {tabel }}$ (Model pembelajaran Cooperative Script efektif pada mata pelajaran Bahasa Inggris di SD Negeri 03 Kalitorong Kabupaten Pemalang)

$H_{0}: t_{\text {hitung }}<t_{\text {tabel }}$ (Model pembelajaran Cooperative Script tidak efektif pada mata pelajaran Bahasa Inggris di SD Negeri 03 Kalitorong Kabupaten Pemalang)

Kriteria pengujian adalah Ha diterima apabila $t_{\text {hitung }}>t_{\text {tabel }}$ dengan $d b=n-1$ dengan taraf signifikan $5 \%$ dan untuk $t_{\text {hitung }} \leq t_{\text {tabel }}$ maka $\mathrm{H0}$ ditolak. Setelah dilakukan analisis data nilai hasil belajar diperoleh rata-rata untuk pretest sebesar 54,8 dan posttest sebesar 77,45 diperoleh $t_{\text {hitung }}=4,297$ dengan tabel distribusi uji t diperoleh $\mathrm{db}=\mathrm{N}-1=20-1=19$ dengan taraf signifikan $5 \%$ didapat nilai $\mathrm{t}_{\text {tabel }}=1,708$. Karena $t_{\text {hitung }}(4,297)>t_{\text {tabel }}(1,708)$ maka hal ini menunjukkan bahwa uji $t$ hasil belajar signifikan. Hal ini menunjukkan bahwa terdapat ada perbedaan secara efektif penggunaan model Cooperative Script terhadap hasil belajar siswa kelas III SD Negeri 03 Kalitorong Kabupaten Pemalang.

Perhitungan yang digunakan untuk mengetahui normalitas data awal sampel menggunakan uji Liliefors, pada taraf signifikan 5\%. Kriteria dalam uji normalitas ini adalah: Lo < Ltabel, maka populasi berdistribusi normal, Lo $\geq$ Ltabel, maka populasi tidak berdistribusi normal

Tabel 3. Hasil Uji Normalitas Akhir (postest)

\begin{tabular}{lllll}
\hline Kelompok & $\mathrm{N}$ & $\mathrm{L}_{0}$ & $L_{\text {tabel }}$ & Kesimpulan \\
\hline Kelas & 20 & 0,0761 & 0,170 & Berdistribusi Normal \\
\hline
\end{tabular}

Berdasarkan Tabel 1.3 perhitungan uji normalitas diperoleh harga mutlak selisih yang paling besar $\mathrm{L} 0=0,0761$ dengan $\mathrm{n}=20$ dan taraf signifikan $=5 \%$ dari daftar nilai kritis $\mathrm{L}$ didapat Ltabel $=0,170$ karena $\mathrm{L} 0<$ Ltabel yaitu 0,0761<0,170 maka $\mathrm{H}_{0}$ diterima sehingga populasi berdistribusi normal.

Hasil penelitian ini menunjukkkan bahwa rata-rata nilai pretest kelas III adalah 54,8 Sedangkan rata-rata nilai posttest kelas III adalah 77,45. Berdasarkan uji hipotesis telah diketahui bahwa terdapat perbedaan pada hasil belajar antara peserta didik saat mendapatkan pembelajaran dengan model cooperative script dan pembelajaran konvensional serta hasil belajar peserta didik dengan model cooperative script ternyata lebih baik daripada yang mendapat pembelajaran konvensional. Keefektifan metode ini juga dapat dilihat dalam proses pembelajaran. Hasil peningkatan dapat dilihat dari ketepatan siswa menemukan gagasan utama dan menentukan letak kalimat utama. Hasil dari penelitian ini sesuai dengan tujuan dari metode Cooperative Script yaitu untuk menjadikan siswa lebih baik memahami materi bacaan. Pembelajaran dengan metode Cooperative Script membuat siswa lebih teliti dan runtut dalam memahami bacaan berdasar script yang telah dibuat. Kelompok eksperimen yang mengikuti pembelajaran dengan menggunakan metode Cooperative Script memiliki antusias yang tinggi dalam proses pembelajaran, kondisi tersebut mempengaruhi hasil belajar siswa.

Menggunakan Model Pembelajaran Cooperative Script memberikan peluang kepada siswa untuk memecahkan permasalahan yang menjadi topik pembelajaran bersama teman sebangkunya, yakni dengan cara melakukan diskusi (Trilarasati, 2014). Cooperative adalah Strategi belajar dimana siswa belajar dalam kelompok kecil yang memiliki kemampuan yang berbeda. Metode Cooperative Script menurut Departemen Nasional yaitu dimana siswa bekerja berpasangan dan bergantian secara lisan mengikhtisarkan bagian-bagian materi yang dipelajari. Pembelajaran Cooperative Script merupakan salah satu bentuk atau model pembelajaran kooperatif.

Hal ini menunjukkan bahwa model Pembelajaran Cooperative Script dinyatakan efektif terhadap hasil belajar siswa kelas III pada mata pelajaran Bahasa Inggris. Penelitian ini juga didukung oleh penelitian yang dilakukan oleh Sufazen (2014) yang menunjukkan bahwa hasil belajar peserta didik yang menggunakan model cooperative script lebih baik daripada yang menggunakan model konvensional. Sejalan dengan itu penelitian yang dilakukan oleh Soelistiyanto (2014) menunjukkan bahwa bentuk pembelajaran dengan menggunakan model Cooperave Script dapat membantu siswa kelas XII IPA3 
SMA Negeri 2 Jember dalam meningkatkan hasil belajar dalam tatanan belajar tuntas Semangat belajar yang tinggi, kerja keras dan doa akan mempengaruhi hasil belajar sehingga dalam proses pembelajaran akan tercipta suasana menyenangkan.

\section{Simpulan dan Saran}

Berdasarkan hasil penelitian yang dilakukan dapat disimpulkan bahwa ada peningkatan dalam penggunaan model pembelajaran Cooperative Script terhadap hasil belajar siswa pada mata pelajaran Bahasa Inggris siswa kelas III SD Negeri 03 Kalitorong Kabupaten Pemalang. Hal ini diperkuat pada analisis tahap akhir dengan uji t diperoleh $=4,297$. Dari daftar distribusi t dengan $d b=20-1=19$ dan taraf signifikan 5\% diperoleh =1,708 Karena kriteria pengujian maka diterima.

Berdasarkan KKM yang ditentukan sekolah yaitu 70, rata-rata hasil belajar siswa yang diberikan perlakuan dengan menerapkan model pembelajaran Cooperative Script yaitu 77,45 telah mencapai KKM Maka dapat disimpulkan terdapat peningkatan pada penggunaan model pembelajaran Cooperative Script terhadap hasil belajar siswa pada mata pelajaran Bahasa Inggris kelas III SD Negeri 03 Kalitorong Kabupaten Pemalang.

Berdasarkan kesimpulan diatas, maka peneliti akan memberikan saran antara lain sebagai berikut: 1. Penggunaan model pembelajaran cooperative script dapat dijadikan guru sebagai inovasi pembelajaran yang aktif, kreatif dan menyenangkan dalam proses pembelajaran, dan 2. Diharapkan penelitian ini dapat dijadikan salah satu refensi dalam melakukan sebuah penelitian oleh peneliti lain dengan materi yang berbeda.

\section{Daftar Rujukan}

Arikunto, Suharsimi. 2014. Evaluasi Hasil Belajar. Yogyakarta: Pustaka Pelajar.

2013. Dasar-dasar Evaluasi Pendidikan. Jakarta: Bumi Aksara.

Arikunto, Suharsimi. 2010. Prosedur Penelitian: Suatu Pendekatan Praktik.. Jakarta: Bumi Aksara.

Ary, D., Jacobs, L.C. \& Razavieh, A. 1976. Pengantar Penelitian Pendidikan. Terjemahan oleh Arief Furchan. 1982. Surabaya: Usaha nasional

Arikunto, S. 1998. Prosedur Penelitian. Jakarta: Rinneka Cipta

Hanafiah \& Suhana Cucu. 2012. Konsep Strategi Pembelajaran. Bandung: PT Refika Aditama

Huda, Miftahul. 2013. Model-model Pengajaran dan Pembelajaran. Yogyakarta: Pustaka Belajar.

Jawa Pos. 22 April 2008. Wanita Kelas Bawah Lebih Mandiri, hlm. 3

Jeremy, Harmer. The Practice of english language Teaching.

Kansil, C.L. 2002. Orientasi Baru Penyelenggaraan Pendidikan Program Profesional dalam Memenuhi Kebutuhan Dunia Idustri. Transpor, XX(4): 54-5 (4): 57-61.

Komsiyah, Indah. 2012. Belajar dan Pembelajaran. Yogyakarta: Teras.

Kumaidi. 2005. Pengukuran Bekal Awal Belajar dan Pengembangan Tesnya. Jurnal Ilmu Pendidikan. Jilid 5, No. 4,

Kuntoro, T. 2006. Pengembangan Kurikulum Pelatihan Magang di STM Nasional Semarang: Suatu Studi Berdasarkan Dunia Usaha. Tesis tidak diterbitkan. Semarang: PPS UNNES

Nur, Edwina Rusvita, Wakidi, Muhammad Basri. 2017. Pengaruh Model Pembelajaran Cooperative Script Terhadap Hasil Belajar Kognitif. PESAGI (Jurnal Pendidikan dan Penelitian Sejarah) Volume 5 Nomor 6.

Pitunov, B. 13 Desember 2007. Sekolah Unggulan Ataukah Sekolah Pengunggulan ? Majapahit Pos, hlm. 4 


\section{$\& 11$.}

Purwanto. 2009. Evaluasi Hasil Belajar. Yogyakarta: Pustaka Pelajar.

Rusman. 2014. Model-model Pembelajaran Mengembangkan Profesionalisme Guru. Jakarta: Raja Grafindo Persada.

Shoimin, Aris. 2014. 68 Model Pembelajaran Inovatif Dalam Kurikulum 2013. Yogyakarta: Ar-Ruzz Media.

Shoimin, Ariz. 2014.68 Model Pembelajaran Inovatif dalam Kurikulum 2013. Yogyakarta: Ar-Ruzz Media

Slameto. 2010. Belajar dan Faktor-faktor yang Mempengaruhinya. Jakarta: Rineka Cipta

Soelistiyanto, Eko. 2014. Penerapan Pembelajaran Model Cooperative Script Untuk Meningkatkan Hasil Belajar Pada Pokok Bahasan Evolusi Di Kelas Xii Ipa3 Sma Negeri 2 Jember. Pancaran, Vol. 3, No. 4, hal 37-46.

Sudjana, Nana. 2014. Dasar-Dasar Proses Belajar Mengajar. Bandung: Sinar Baru Algensindo.

Sufazen, Nurulita. 2014. Keefektifan Model Cooperative Script Terhadap Hasil Belajar IPS. Journal of Elementary Education (JEE) Volume $3 \quad$ (2) diakses melalui http://journal.unnes.ac.id/sju/index.php/jee.

Sugiyono. 2015. Metode Penelitian Pendidikan. Bandung: Alfabeta, cv

Suprijono, Agus. 2013. Cooperative Learning Teori dan Aplikasi Paikem. Surabaya: Pustaka Pelajar

Susanto, Ahmad. 2013. Teori Belajar dan Pembelajaran di Sekolah Dasar. Jakarta: Kencana.

Trilarasati, Yuli , Iskandar Syah dan Muhammad Basri. 2015. Pengaruh Model Pembelajaran Cooperative Script Dalam Meningkatkan Prestasi Belajar Siswa. PESAGI (Jurnal Pendidikan dan Penelitian Sejarah) Volume 2 Nomor 1.

Waseso, M.G. 2001. Isi dan Format Jurnal Ilmiah. Makalah disajikan dalam Seminar Lokakarya Penulisan artikel dan Pengelolaan jurnal Ilmiah, Universitas Lambungmangkurat, 9-11Agustus

Ysh, Soegeng. 2016. Dasar-dasar Penelitian. Yogyakarta: Magnum Pustaka Utama. 